\section{Infrapatellar fat pad resection during total knee arthroplasty: yet another reason for?}

There has been an interesting series of commentaries based on the initial paper by Pan et al. ${ }^{1-4}$ I note with interest the suggestion by Binks et $a l^{4}$ that to preserve the infrapatellar fat pad (IPFP) and perform later arthroscopic resection on a case by case basis may be a viable option for management of anterior knee pain (AKP) after total knee arthroplasty (TKA). This is contrary to the solution offered by Han $e t a l^{3}$ to use a prospective MRI to screen patients prior to TKA with subsequent resection based on signal changes within the IPFP. This approach would however, prove difficult in the resource-constrained environment of most primary care facilities.

Current arguments in support of preserving the IPFP are largely based around the incidence of postoperative AKP. ${ }^{56}$ One area of conflicting evidence is the incidence of patella tendon shortening, also known as patella baja, after resection. Recent studies have shown no significant effect on postresection patella tendon length. ${ }^{78}$ This suggests that postresection patella tendon length is unlikely to be a major factor when considering to resect the IPFP or not.

The most common argument for IPFP resection is the increased surgical access to the knee. It is widely accepted that the most important aspect of knee arthroplasty is the correct fitting of components. ${ }^{9}$ Only with correctly fitting components can normal function be attained. In order to achieve this 'correct fit' the IPFP is often resected. Although this is a logical argument, there is no objective evidence in support of this.

The study by Sekiya et $a l^{10}$ showed that in patients with AKP following resection there was a significant proportion with scar tissue deep to the tendon. So perhaps it is insufficient resection and not the decision to remove the IPFP that results in AKP. And with recent studies showing a lack of patella tendon shortening post IPFP resection, limiting one argument for its preservation, this may be more accepted in the future.

\section{Thomas J Ryan}

Correspondence to Dr Thomas I Ryan, Department of Orthopaedics, John Hunter Hospital, Newcastle, NSW 2305, Australia; Tom-ryan@hotmail.com

Funding The authors have not declared a specific grant for this research from any funding agency in the public, commercial or not-for-profit sectors.
Competing interests None declared.

Patient consent Not required.

Provenance and peer review Not commissioned; internally peer reviewed.

(c) Article author(s) (or their employer(s) unless otherwise stated in the text of the article) 2019. All rights reserved. No commercial use is permitted unless otherwise expressly granted.

\section{Check for updates}

To cite Ryan TJ. Ann Rheum Dis 2019;78:e63.

Accepted 2 May 2018

Published Online First 15 May 2018

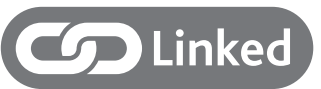

- http://dx.doi.org/10.1136/annrheumdis-2018-213701

Ann Rheum Dis 2019;78:e63. doi:10.1136/annrheumdis-2018-213684

\section{REFERENCES}

1 Pan F, Han W, Wang $X$, et al. A longitudinal study of the association between infrapatellar fat pad maximal area and changes in knee symptoms and structure in older adults. Ann Rheum Dis 2015;74:1818-24.

2 White LD, Melhuish TM. The role of infrapatellar fat pad resection in total knee arthroplasty. Ann Rheum Dis 2016;75:e66.

3 Han W, Pan F, Liu Z, et al. Response to: 'The role of infrapatellar fat pad resection in total knee arthroplasty' by White et al. Ann Rheum Dis 2016;75:e67.

4 Binks MJ, Vlok R, Holyoak R, et al. Preoperative MRI to plan infrapatellar fat pad resection during total knee arthroplasty. Ann Rheum Dis 2017;76:e34.

5 White L, Holyoak R, Sant J, et al. The effect of infrapatellar fat pad resection on outcomes post-total knee arthroplasty: a systematic review. Arch Orthop Trauma Surg 2016;136:701-8.

6 Duan G, Liu C, Lin W, et al. Different factors conduct anterior knee pain following primary total knee arthroplasty: a systematic review and meta-analysis. J Arthroplasty 2018.

7 Sellars H, Yewlett A, Trickett R, et al. Should we resect hoffa's fat pad during total knee replacement? J Knee Surg 2017;30:894-7.

8 Imren Y, Dedeoğlu SS, Çakar M, et al. Infrapatellar fat pad excision during total knee arthroplasty did not alter the patellar tendon length: a 5-year follow-up study. J Knee Surg 2017;30:479-83.

9 White L, Stockwell T, Hartnell N, et al. Factors preventing kneeling in a group of preeducated patients post total knee arthroplasty. J Orthop Traumatol 2016;17:333-8.

10 Sekiya H, Takatoku K, Takada H, et al. Painful knee after total knee arthroplasty is not a frequent complication and could be treated by arthroscopic debridement. Bone Joint J 2016;98(Suppl 3):152. 